\title{
The readiness of human resources and organization in implementing total quality management (TQM) in Indonesia's manufacturing industries
}

\author{
Farida Farida, Herry Agung Prabowo* and Achmad Husnur \\ Department of Industrial Engineering, Universitas Mercu Buana Jakarta, Jalan Meruya Selatan Raya, Kembangan Jakarta Barat, \\ 11650, Indonesia \\ *Corresponding Author: herry_agung@mercubuana.ac.id
}

$\begin{array}{ll}\text { Submitted } & : 09 / 03 / 2020 \\ \text { Revised } & : 16 / 10 / 2020 \\ \text { Accepted } & : 25 / 10 / 2020\end{array}$

\begin{abstract}
Total Quality Management (TQM) is a method of organizational improvement that is quite widely used in the world. Unfortunately, there are still many failures in its implementation, especially in Indonesia, for many reasons. The aim of this study was to determine the readiness of organizations and individuals in implementing TQM and its influence on the quality performance in Indonesia's manufacturing industries. The sample of this research consisted of 48 employees from about 20 privately owned companies at Jakarta, Bogor, Depok, Tangerang, and Bekasi (Jabodetabek) areas, Indonesia. The data were collected through interviews and questionnaires, followed by statistical analysis with Structural Equation Modelling using Partial least squares (PLS) method. The results of this study indicated that, within the sector, the individual and organizational readiness in implementing TQM, as well as their quality performance, was found to be at a good level. Furthermore, the level of individual and organizational readiness in implementing TQM showed a significant effect on the quality performance, with the significance levels of $84 \%$ and more than $99 \%$, respectively. Accordingly, 43\% variation on quality performance was influenced by the individual and organizational readiness in implementing TQM, and the rest (57\%) was influenced by other factors.
\end{abstract}

Keywords: Individual readiness; Organizational readiness; Quality performance; Qanufacturing industries; Total quality management.

\section{INTRODUCTION}

In terms of production processes, few companies have adopted modern manufacturing concepts such as Total Quality Management (TQM), Total Productive Maintenance (TPM), Just in Time /Kanban systems, and Toyota Production System (TPS), which is now called the Lean Manufacturing (LM) strategy. By applying one of the modern manufacturing concepts mentioned, a company will be able to improve its performance through the reduction of various types of waste, increasing the availability and reliability of machinery, decreasing the defect and reject products, reducing energy consumption, and increasing profit. One of the most important tools of LM is TQM, which is also known for its integrated quality management. According to Anvari, et.al (2011), TQM is an approach of running a business which seeks to maximize the competitiveness of the organization through continuous 
improvement of its products, services, labor, processes and environment. Accordingly, TQM should be able to increase the added value through waste reduction by decreasing the defect and reject products.

Some empirical studies have explained that the social, cultural, and economic conditions of a country may have the potential to improve TQM practices in a company Shafiq, et.al (2019), Forza and Flippini (1998), Flynn and Saladin (2006) also suggested that the relationship between TQM and organizational performance needs to be examined in the context of other countries. Research by Feng et.al. (2006), have concluded that customer satisfaction and process management in Australia manufacturing and services are more related to quality performance. Only leadership and process management in USA Manufacturing have a direct positive relationship with business results (Sila and Ebrahimpour (2005)). Kull and Wacker (2010) have found significant differences in the application of quality management practices among companies located in East Asian cultures of China, Taiwan and South Korea. The soft elements of TQM such as human resource, quality culture, relationship management, and motivational leadership are significant positive determinants of financial performance (Dubey and Gunasekaran (2015)). Othman et al. (2020) conclude that employee related factor was identified to be the most crucial factors affecting TQM implementation.

Sila and Ebrahimpour (2005) state that the relationship between TQM and organizational performance needs to be explored in a particular country context. From several literature studies conducted by Shafiq, et al. (2019) leads to the conclusion that the relationship of TQM with different dimensions of organizational performance cannot be concluded; therefore, further empirical research is needed to investigate this relationship in more depth. Haffar et al. (2013) developed a model of the influence of organizational culture on TQM implementation mediated by individual readiness for change. The model developed by Haffar shows that IRFC has a strong mediating role in the relationship between the implementation of organizational culture and TQM. This model also implies that the cultural hierarchy lacks significance for the successful implementation of TQM. Haffar et al. (2014) believed that individual change readiness is strongly related to TQM and, serve each other as augmentation. He also stated that if change readiness is prevailed in organizational culture, then TQM practices can be implemented properly (Haffar et al., 2016).

Weiner, B. (2009) stated that when organizational readiness for change is high, organizational members are more likely to initiate change, exert greater effort, exhibit greater persistence, and display more cooperative behavior. Therefore Vakola, M. (2013) explained that creating individual readiness for change should be viewed as an integral part of planning, implementing and evaluating organizational change, because recipients' beliefs and perceptions of their organization level of readiness have an impact on their acceptance and adaptation to change.

Chase, et al. (2005), emphasized that TQM is a new paradigm in running a business that seeks to maximize organizational competitiveness through a focus on customer satisfaction, involvement of all employees, and continuous improvement of the quality of products, services, people, processes and the organizational environment. TQM has been widely applied by many companies with the aim of improving performance such as quality, productivity and profitability (Krajewski, et al., 2006). The role of TQM, in addition to being a quality management system, can also improve quality performance as a mediator in achieving superior business performance (Munizu, M. et al. 2012). This study was conducted to fill the gap from the model developed by Haffar (2013) by including the organizational readiness for change variable and examining the effect of individual readiness and organizational readiness to implement TQM on quality performance.

\section{TOTAL QUALITY MANAGEMENT AND QUALITY PERFORMANCE}

TQM is a management approach that focuses on quality as a business strategy by involving all members of the organization in an oriented effort to improve the quality and customer satisfaction continuously. The recent results of several empiric research have proved that an organization business performance was directly and indirectly 
influenced by the successful implementation of TQM in that particular organization (Shafiq, 2019). Furthermore, Yusof, (1999) stated that TQM is a new paradigm in running a business. TQM was generally implemented by many companies with the purpose of increasing the performances of quality, productivity and profitability. Nowadays, the implementation of TQM in organizations is really important to achieve competitive advantages. TQM plays an important role as a mediator to reach business performance superiority (Munizu, et. al 2012). Meanwhile, according to Anvari et al. (2011), TQM is a commitment of the organization to fulfill the customer's satisfaction through continuous improvement of the business process, product and services.

It was previously explained that the role of TQM is to increase quality performance as a mediator, in order to reach business performance superiority (Munizu, et.al 2012). Meanwhile, Brah \& Lim (2006) explained that a company's performance can be measured by its own operational performance. This internal operational performance, which consists of cost and wastage reductions, increases of product quality, and development of new product, will repair delivery performance and increase productivity (Prajogo, 2003; 2005) concluded that the implementation of TQM gave a significant positive impact in terms of performance quality. This statement can be understood in terms that TQM is focused on the achievement of performance quality. Australian and New Zealand manufacturing (AMC) in Corbet and Rastrick (2000) determine the quality performance indicators consisting of the percentage of defective materials received from suppliers, percentage of defective products from the total production, percentage of assurance fee claimed from the total selling, percentage of quality fee (error, scrap, rework and inspection) from total selling, and percentage of on-time delivery to the customers.

\section{ORGANIZATIONAL READINESS TO CHANGE}

The success and failure of TQM implementation is based on the competency of the human resources in that particular company. The implementation by human resource management is not stand-alone, but it is pivotal to the TQM package and must be aligned with the process changes. Thus, the success of TQM and other modern manufacturing programs depend on organizational readiness, especially the readiness of human resources in accepting the transformations. Nowadays, in the dynamic business environment, an organization still has to face changes initiative such as TQM as a management strategy, which is developed to increase the effectiveness and competitiveness of the organization (Prajogo, 2003; 2005). Without doing any transformation, an organization will lose its ability to compete, and without introducing adequate timely and ethical changes, an organization will also face hard times and decrease their chances significantly for long term survival (Theureur, 2018). The employee's perception is essential to the organization's ability in accommodating transformation through the amendment of policies and procedures, which is related to the readiness of the organization to change (Eby, 2000) Also, it can be said that the variable of the individual attitude and references, working group, and working attitude are among the important roles to comprehend the organization's readiness in order to change. The attitude change is intended to increase the level of supervisor support to the employees. Moreover, Caudron in Mcnabb, (1995) stated that it is important for a company to give a training which focuses on the consciousness, process repairing, and training which is intended to prepare the attitude and skills needed for creating the changes brought by TQM implementation.

\section{INDIVIDUAL READINESS TO CHANGE}

In order to change successfully, an organization must be ready to change. Nevertheless, the organization's readiness must also be supported by employees' fair in embracing the change (Ebi, 2000). Moreover, the human being factor and their attitude are important while implementing Lean Six Sigma in the manufacturing small and medium-sized enterprises (SMEs). TQM is a philosophy, management approach, and organization's cultural 
management which focuses on the cooperation reciprocity that includes everyone in the organization at every level, as well as the improvements in all aspects of the organization (Haffar, 2013).

All kinds of organizations, multinational or local, are facing the needs in adopting strategies changes. Moreover, in the competitive global economy nowadays, many organizations all over the world adopt and implement the quality improvement program (e.g. TQM) effectively as their management strategy (Ahmad et al. 2012; Zairi, 2013; Ohtaki, 2016). The recent literature in TQM showed that there is an increase of admission for the individual readiness in organizations which influences the changes that define the success or failure of TQM implementation (Haffar, 2013; Meirovich, 2006). Furthermore, Haffar et al. (2013) found that individual readiness in the implementation of TQM in Algeria's manufacturing organizations was valid and created based on four indicators. Thus, the success in implementing the initiative for changes is one of the consequences of those four indicators. Accordingly, Sila, (2007) concluded that human resource management is essential to create TQM implementation.

\section{MATERIAL AND METHOD}

The modelling of individual and organizational readiness to implement TQM towards quality performance was carried out using Structural Equation Modeling (SEM) with SmartPLS program (SmartPLS GmbH). The use of SEM methods that treat individual and organizational readiness to implement TQM and quality performance variables as construct variables is still limited. In this study, the variables of individual and organizational readiness to implement TQM and quality performance were treated as unobserved variables. These variables are measured through the indicators.

\section{a. Data Collection Technique}

This study was conducted with individual human resources and manufacturing organizations in the industrial center of Jabodetabek, Indonesia. The data were collected through the distribution of questionnaires to 100 operatorlevel employees from 20 privately owned companies of Indonesia's manufacturing sector at Jabodetabek, Indonesia. The valid data for analysis were collected from 48 respondents. According to Baley in Mahmud (2011), for research to employ statistical data analysis or correlational descriptive methods, the minimum size of the sample should be thirty. Thus, the number of samples in this study can be considered as sufficient.

\section{b. Variable and Measurements}

The research questionnaire was used to collect the research variable based on the opinion about the readiness of individual (IRFC) and the readiness of organization (ORFC) in implementing TQM and manufacturing quality performance $(\mathrm{QP})$. The individual readiness variable (IRFC), which measures the level of individual readiness to employ changes in terms of TQM implementation, was measured towards several indicators developed by Holt et al.

(2007). Those indicators are as follows: (1) personal benefit, (2) management support (leader and management positions with commitment and support for the implementation of prospective changes), (3) change efficacy (a selfconfidence), and (4) appropriateness (the appropriate approach in conducting the changes).

The ORFC variable, which measures the level of an organization's readiness in conducting changes, was also applied for the implementation of TQM as a construct, which was intended as the organization's readiness variable to conduct the changes as presented by Lameei (2005). Those indicators are as follows:

(1) TQM training opportunities for employees

(2) Existence of TQM support structure. 
(3) The arrangement of TQM training program.

(4) Common language and terminology application on the concept, principle, and method of TQM.

(5) Human resources application in creating appropriate TQM.

(6) Focus on customers.

(7) The stress of culture quality.

(8) Engagement of all employees in the effort to improve quality.

(9) Appreciation for the functional team working.

(10) Implementation and realization of continuous improvement.

(11) Acknowledgement and appreciation for the achievement in quality improvement.

The indicators of individual and organizational readiness in implementing TQM were measured by using a 1to-5 Likert scale. The applied indicator measurement for QP was based on the Australian and New Zealand Manufactures (AMC) in Corbet dan Rastrick (2000), as explained by Holt et al. (2007). Table 1 shows the details of those measurements.

Table 1. Value of the quality performance indicators.

\begin{tabular}{|c|c|c|}
\hline Indicator of Quality Performance & $\%$ & Score \\
\hline $\begin{array}{l}\text { The percentage of defective materials } \\
\text { received from suppliers }\end{array}$ & $\begin{array}{l}<0.10 \\
0.1-0.49 \\
0.5-1.99 \\
2.0-5.0 \geq 5.0\end{array}$ & $\begin{array}{l}5=\text { very low } \\
4=\text { low } \\
3=\text { good } \\
2=\text { high } \\
1=\text { very high }\end{array}$ \\
\hline $\begin{array}{l}\text { Percentage of defective products from the } \\
\text { total production. }\end{array}$ & $\begin{array}{l}<0.10 . \\
0.1-0.49 \\
0.5-1.99 \\
2.0-5.0 \\
\geq 5.0\end{array}$ & $\begin{array}{l}5=\text { very low } \\
4=\text { low } \\
3=\text { good } \\
2=\text { high } \\
1=\text { very high }\end{array}$ \\
\hline $\begin{array}{l}\text { Percentage of assurance fee claimed from } \\
\text { the total selling. }\end{array}$ & $\begin{array}{l}<0.10 \\
0.1-0.99 \\
1-1.49 \\
1.5-3.0 \\
\geq 3.0\end{array}$ & $\begin{array}{l}5=\text { very low } \\
4=\text { low } \\
3=\text { good } \\
2=\text { high } \\
1=\text { very high }\end{array}$ \\
\hline $\begin{array}{l}\text { Percentage of quality fee (error, scrap, } \\
\text { rework and inspection) from total selling. }\end{array}$ & $\begin{array}{l}<1 \\
1-4.9 \\
5-9.9 \\
10.0-15.0 \\
\geq 15.0\end{array}$ & $\begin{array}{l}5=\text { very low } \\
4=\text { low } \\
3=\text { good } \\
2=\text { high } \\
1=\text { very high }\end{array}$ \\
\hline $\begin{array}{l}\text { Percentage of on-time delivery to the } \\
\text { customers. }\end{array}$ & $\begin{array}{l}97-100 \\
91-96 \\
81-90 \\
50-80 \\
<50\end{array}$ & $\begin{array}{l}5=\text { very low } \\
4=\text { low } \\
3=\text { good } \\
2=\text { high } \\
1=\text { very high }\end{array}$ \\
\hline
\end{tabular}




\section{RESULT AND DISCUSSION}

\section{a. Respondents Characteristics}

This study involved employees who work as a human resource from various backgrounds in Indonesia's manufacturing industries. Figure 1 depicts the percentage of the available human resources and the respective type of the industry.

The total respondents who were working in the electronic and computer industry, as well as oil, chemicals, and plastic industry, had a percentage of $26.3 \%$ and $21.2 \%$, respectively. The accumulated percentage of respondents who were working in the

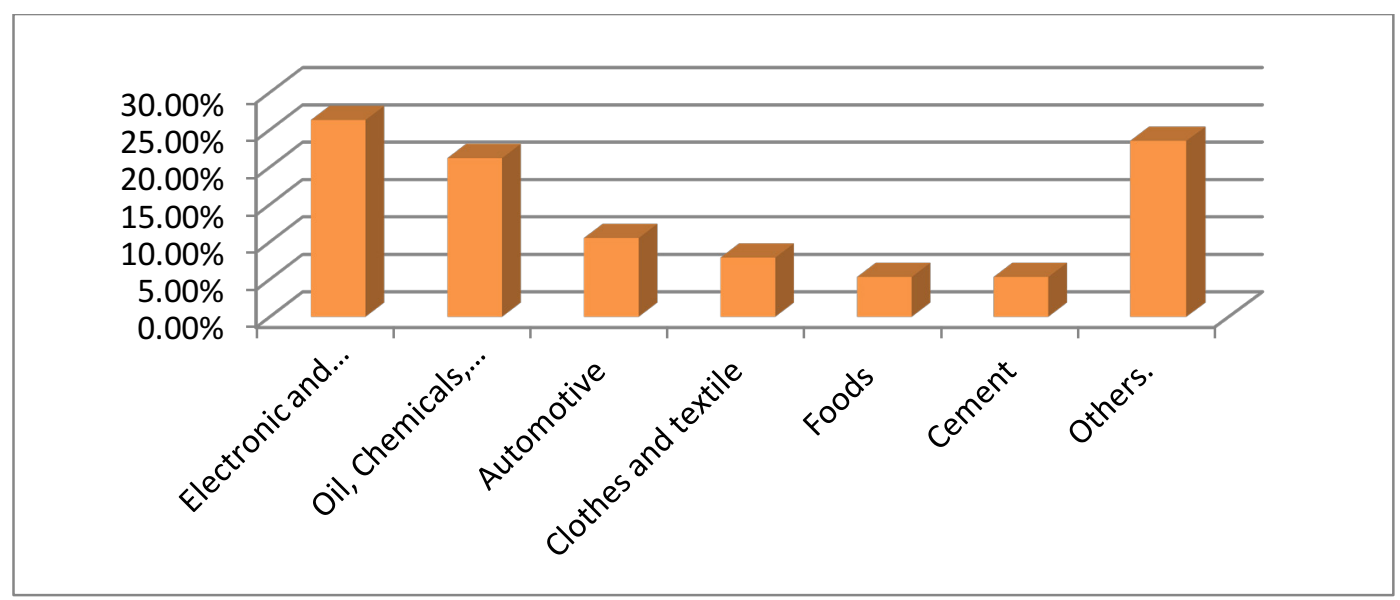

Figure 1. The Characteristics of the Manufacturing Industries.

automotive, clothes and textile, foods, and cement industries were about $29 \%$, while $23.5 \%$ accounted for workers in other manufacturing industries. On the other hand, the manufacturing industries with total employees of more than 100 were represented by the highest total percentage of $78.9 \%$, while the industries with total workers less than 20 and $20-100$ people comprised of $0 \%$ and $21.1 \%$, respectively. Hence, the sample of the respondents in the present study involved the workers from medium and large-scale industries.

The respondents were also characterized by their education, working experience, and their understanding in quality management topic, as depicted in Figure 2, 3 and 4. The characteristics of the respondents with their highest percentages, based on education, working experience, and TQM comprehension were senior high school (secondary school) (also known as Sekolah Menengah Atas or SMA) or secondary vocational school (also known as Sekolah Menengah Kejuruan or SMK) (71.7\%), working experience of less than five years $(70.2 \%)$ and comprehend the TQM concept (87.8\%), respectively. 


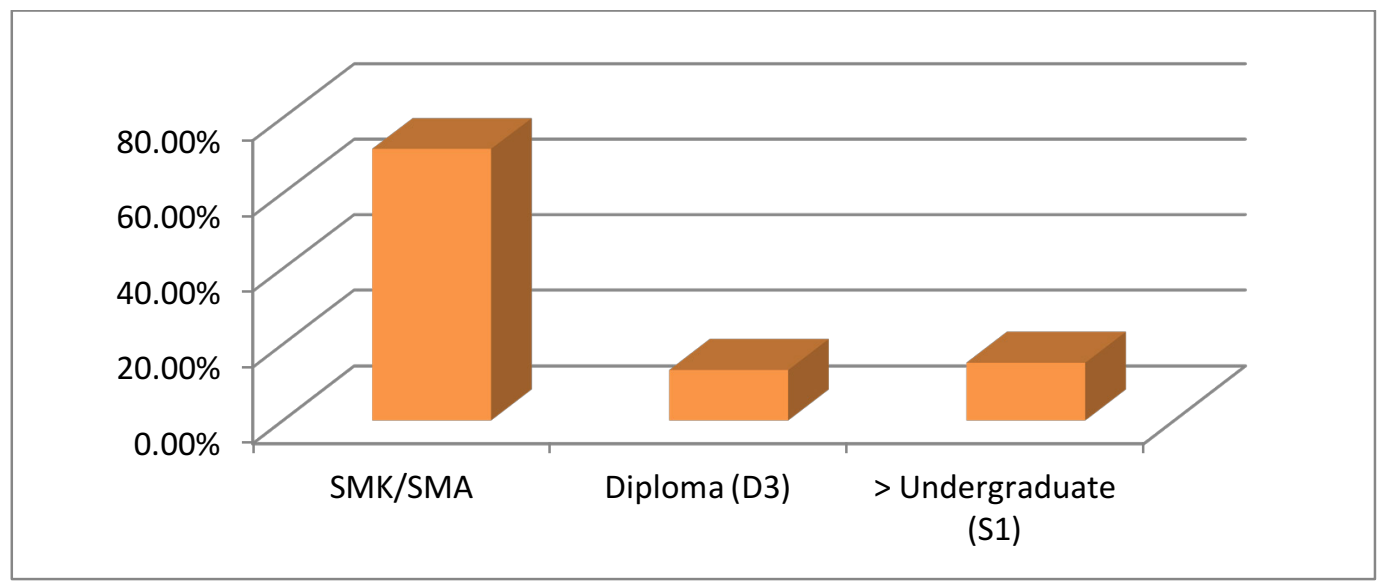

Figure 2. Education level of the respondents.

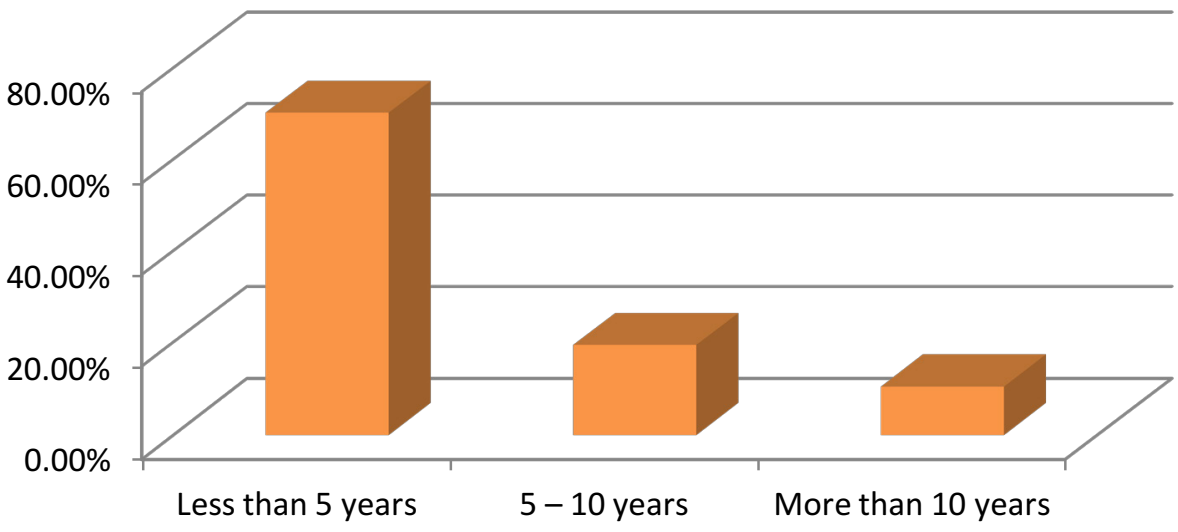

Figure 3. Work experience of the respondents.

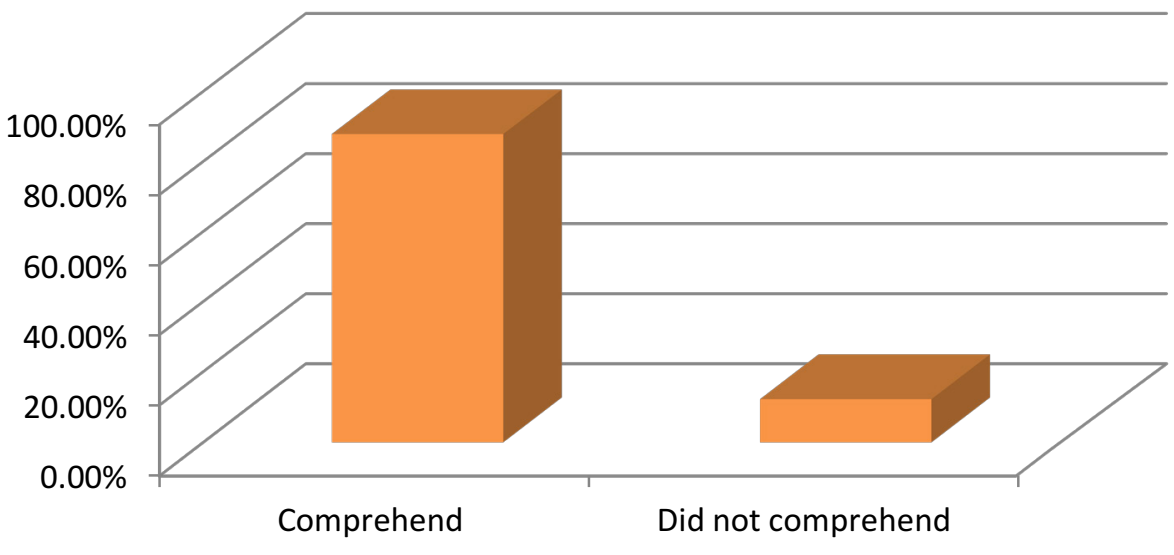

Figure 4. Comprehension of Total Quality Management (TQM). 


\section{b. The Level of Individual and Organizational Readiness to Implement TQM and Quality Performance in Indonesia's Manufacturing Industries}

Generally, the individual readiness of Indonesia's manufacturing sector in TQM implementation is satisfactory. Table 2 shows that all individual readiness indicators in implementing TQM have the average value larger than four with the highest mode value of 4.00. The level of organizational readiness in implementing TQM is presented in Table 3.

In general, the organization's readiness indicators have mean values of more than 3.50 and 4.00 mode values, except for the indicators of TQM training opportunities for employees, and the common language on the concept, principle, and methods of TQM. Table 4 presents the quality performance of the manufacturing industries. The mean values of the quality performance (the percentage of defective materials input by supplier, defective products from the total production, fee of claim and fee of quality from the total selling, and the percentage of delivery delays) are more than 3.50 with mode values of 4.00 .

Table 2. Individual readiness to implement TQM.

\begin{tabular}{llcc}
\hline & \multicolumn{1}{c}{ Variable/Indicator } & Mean & Mode \\
\hline 1 & Personal benefit (Individual advantage) & 4.00 & 4.00 \\
\hline 2 & $\begin{array}{l}\text { Management support (Leader and management commit and } \\
\text { support the implementation of TQM) }\end{array}$ & 4.08 & 4.00 \\
\hline 3 & Change efficacy (a self-confidence) & 4.02 & 4.00 \\
\hline 4 & $\begin{array}{l}\text { Appropriateness (Accurate reason in conducting changes, and } \\
\text { congruence between the company and the purpose of changes) }\end{array}$ & 4.21 & 4.00 \\
\hline
\end{tabular}

Note: $5=$ very good, $4=$ good, $3=$ satisfactory, $2=$ bad, $1=$ very bad

Table 3. Level of organization's readiness to implement TQM.

\begin{tabular}{lcc}
\hline \multicolumn{1}{c}{ Indicator } & Mean & Mode \\
\hline $\begin{array}{l}\text { 1. TQM Training opportunities for employees } \\
\text { 2. Existence of TQM support structure }\end{array}$ & 3.21 & 3.00 \\
$\begin{array}{l}\text { The arrangement of TQM training program } \\
\text { 4. Common language on the concept, principle, and } \\
\quad \text { methods of TQM }\end{array}$ & 3.68 & 4.00 \\
\hline
\end{tabular}


5. Human resources application in creating appropriate TQM

6. Focus on customers

7. The stress of culture quality

8. Engagement of all the employees as the effort to increase the quality

9. Appreciation for the functional team working

10. Implementation and realization of continuous improvement

11. Acknowledgement and appreciation for the achievement in quality improvement
3.58

Note: $5=$ very good, $4=$ good, $3=$ satisfactory, $2=$ bad, $1=$ very $b a d$
4.00

Table 4. Quality Performance of Indonesia's Manufacturing Industry.

\begin{tabular}{llcc}
\hline \multicolumn{1}{c}{ Indicator } & Mean & Mode \\
\hline 1 & Percentage of defective materials from suppliers & 3.97 & 4.00 \\
2 & Percentage of defective products & 4.13 & 4.00 \\
. & & & \\
3 & Percentage fee of claim & 3.89 & 4.00 \\
4 & $\begin{array}{l}\text { Percentage fee of quality (error, scrap, etc) from the total } \\
\text { selling }\end{array}$ & 4.13 & 5.00 \\
5 & $\quad$ Percentage the delivery delays & 3.82 & 4.00 \\
\hline
\end{tabular}

Note: $5=$ very good, $4=$ good, $3=$ satisfactory, $2=$ bad, $1=$ very bad

\section{c. The Evaluation of Measurement Model (Outer Model)}

An outer model was generated to provide an overview of the relationship between the latent variables (constructs) with each indicator. This model helps to illustrate the effect of the variables towards the indicators as well as the validity from the variables of the research. 
According to Ghozaly in Prabowo (2018), an indicator is considered to be convergent valid if the loading factor value is higher than 0.5. Figure 5 shows that ORFC9 (Appreciation for the working functional team) is an invalid indicator created from its variable.

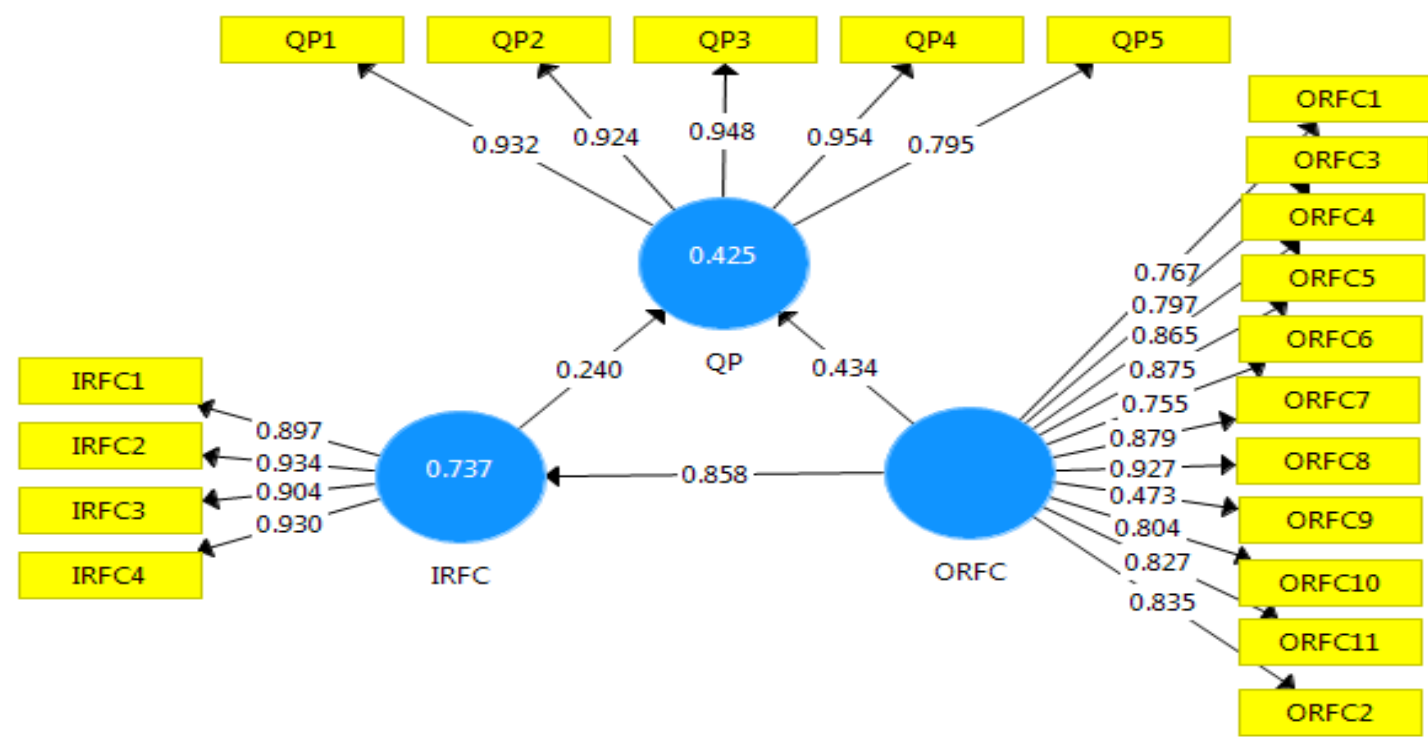

Figure 5. The Influence of Individual and Organizational Readiness on Quality Performance (Model 1).

In the consecutive stage of reliability test with the Cronbach's alpha value, a variable can be considered to be reliable if it has Cronbach's alpha value of more than 0.6 (Ghozali in Adesta, 2018). Any variable with a value of less than 0.6 will be dropped out of the model. The result of the reliability test from research variables can be seen in Table 5. Table 5 shows that all variables have Cronbach's alpha values of more than 0.6. Thus, all variables were considered to be reliable and therefore can be used as the research instruments. Accordingly, the followed-up analysis of the reliability test involved the removal of ORFC9 from the model. The generated model without ORFC9 showed all indicators to be valid to create construct, because their loading factor values were higher than 0.50 .

\section{d. The Evaluation of Structural Model (Inner Model)}

According to Ghozali \& Latan (2015), the evaluation of structural model (inner model) in PLS analysis consists of a significance test and an $\mathrm{R}^{2}$ endogenous variable calculation. The model of statistical significance test was conducted using bootstrapping (resampling) method.

At the confidence interval of $95 \%$, the exogenous variables significantly influenced the endogenous variables when the value $\mathrm{p}$-value is $<0.05$. The value of $\mathrm{R} 2$ was used to give a score in measuring the influences of dependent latent variable to the independent latent variable.

The result of the Significance test is tabulated in Table 6. The ORFC variable has a p-value of $<0.05$ which influenced the significance of IRFC and QP. Therefore, it was implied that the ORFC influenced the IRFC and QP with a significance level of more than 95\%. Meanwhile, IRFC variable also influenced QP with a significance level of $84 \%$. Figure 6 shows that the value of R2 was 0.429 , or less than $43 \%$, which implies the influence of QP variation, at $43 \%$ interval, towards the variations of IRFC and ORFC in the implementation of TQM. As much as $57 \%$ variation 
on QP was influenced by the variation of other variables, aside from IRFC and ORFC. Figure 6 also shows that ORFC influenced the significance of IRFC in the implementation of TQM, where the variation of IRFC was $73 \%$ influenced by the variation of ORFC.

Table 6. The Result of Significance Test.

\begin{tabular}{|c|c|c|c|c|c|}
\hline \multicolumn{3}{|c|}{ Variable } & Standard & t- & P- \\
\hline Organizational Readines. & $\longrightarrow$ & Individual Readiness & 0.028 & 30.333 & 0.000 \\
\hline Organizational Readines & $\rightarrow$ & Quality Performance & 0.193 & 2.360 & 0.018 \\
\hline Individual Readiness & $\rightarrow$ & Quality Performance & 0.160 & 1.375 & 0.163 \\
\hline
\end{tabular}

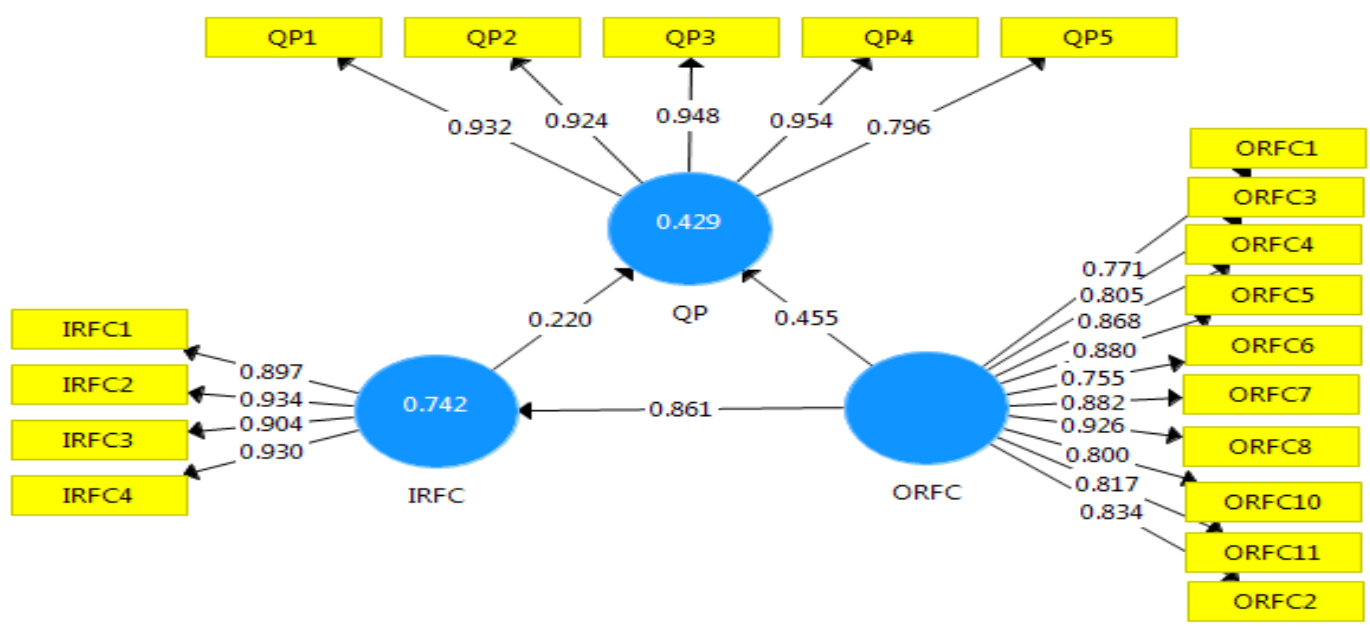

Figure 6. The Influence of Individual and Organizational Readiness on Quality Performance (Model 2).

\section{e. Goodness-of-Fit (GoF) Test}

The goodness-of-fit test of the model in this study was calculated by the values of standardized root mean square residual (SRMR), exact model fit (d_ULS), Chi-Square, and normed fit index (NFI), with the limit of critical criteria determined by Dijkstra et al. (2015). Based on the criteria of the GoF test values (Table 7), it can be seen that the model can be accepted as a good model. 
Table 7. The Result of Goodness-of-Fit Test.

\begin{tabular}{lccc}
\hline $\begin{array}{c}\text { Goodness of } \\
\text { Fit Index }\end{array}$ & Saturated Model & $\begin{array}{c}\text { Estimated } \\
\text { Model }\end{array}$ & Cut off value \\
\hline SRMR & 0.084 & 0.084 & $0.08-0.1$ \\
d_ULS & 1.337 & 1.337 & $>0.05$ \\
Chi-Square & 720.675 & 720.675 & High values \\
\hline
\end{tabular}

\section{f. Discussion}

Almost $90 \%$ of the workers have a good comprehension on the concept of TQM. With that condition, the individuals who are working in Indonesia's manufacturing sector have the readiness to implement TQM satisfactorily. The individuals (human resources) of the sector stated that, through the implementation of TQM, they have gained a lot of advantages. In addition, the leaders and management of the companies have shown their support towards the realization of TQM. Furthermore, they have shown a great self-confidence and self-ability to implement TQM, and they felt that the decision to implement TQM is already correct, which also very much support the purpose of the company.

The manufacturing companies sampled in this study have the readiness to implement TQM effectively. Most of them already have the structures to support the realization of TQM, including the arrangement of TQM training program, the standardization of the general language (jargon) on the concept, principle, and method of TQM, the human resources which employ the appropriate TQM, the focus on customers aspect, the stress of culture quality, the engagement of all employees as the effort to increase quality, the appreciation to the functional teamwork, the implementation and realization of continuous improvement, the acknowledgement and appreciation for the achievement in quality improvement. Meanwhile the quality performance of these industries was also in satisfactorylevel, where the percentage of defective material input from suppliers, defective products from the total production, fee of claim and quality of the total selling, as well as the percentage of delivery delays, suggest them low in terms of level. Interestingly, the result was found to be comparable with the research result from Pasaribu (2009) which concluded that the level of TQM basic implementation in 25 Indonesia's manufacturing state-owned enterprises (Badan Usaha Milik Negara or BUMN) had the average value of 3.6429, so that it can be classified as a wellimplementation of basic TQM category. Similarly, the research conducted by Amar \& Zain in Novrianto et al. (2014), revealed that all Indonesia's arms industry has been implementing TQM optimally.

This study also showed that the organizational readiness in implementing TQM significantly influenced the quality performance with the confidence interval of more than $95 \%$, while the individual readiness in implementing TQM influenced the quality performance with a confidence interval of $84 \%$. The result of this study similar to the result presented by Munizu et al. (2013), which explained that the implementation of TQM gave a positive impact on the product's quality performance. Sahooa, S. et al. (2020) stated that there is a strong and positive relationship between the simultaneous implementation of TQM with operational performance parameters. Research by Iqbal, A. et al. (2018) explains that individual readiness and TQM practices provide significant support for measuring 
employee performance. Although organizational readiness and individual readiness in implementing TQM have the same significant effect, this research proves that organizational readiness has a stronger influence on quality performance than individual readiness.

Other findings from this research are that organizational readiness in implementing TQM has a significant effect on individual readiness in implementing TQM , and as much as $75 \%$ of the individual readiness variation in implementing TQM was influenced significantly by the variation of organizational readiness. These results are in line with the findings of Almaamari, Q. et al. (2018), who state that management, learning and training processes, focus on customer satisfaction, which are indicators of organizational readiness to implement TQM have an effect on individual readiness to change. This mean that the strong management commitment and consistency to the implementation of TQM in the organization are critical in determining the product quality performance. The development of product quality programs in TQM framework could run efficiently if the programs get sufficient support from leader/management of the company. Haffar, et al. (2013) said the importance of preparing organizational members to be ready to achieve successful implementation of change, in other words the organization must be ready to create individuals to be ready to implement TQM. This statement is supported by Prajogo (2003) who stated that the organization's performance in realizing TQM significantly and positively affect the quality performance. It is also supported by the statement of Mustafa \& Bon in Farida (2019) who stated that top management commitment is a critical role in establishing TQM systems as modern quality management.

Moreover, Weeks et al. (2004) also stated that the positive employee's perception to the organization readiness created a positive impact on the manager's performance. Meirovich et al. (2006) and Haffar et al. (2016) believed that ignorance on the strategic values and employee's role during the implementation of TQM, as well as the lack of individual readiness to changes, caused the implementation of TQM to be unsuccessful. Furthermore, it was explained that the employee's perception on the ability of the organization to accommodate the changing situations through policies and procedures relates to their perception on the organization readiness to change. The organization was suggested to give more attention, support, and participation towards the employees. This condition can increase the self-confidence level of the employees towards the organization's ability to transform and to create a continuous momentum to preserve changes Ebi (2000). A conducive environment must be created for employees, one of which is top-down communication and employee-friendly policies (Roslin, 2019). The organization's readiness to face changes influence the changing process itself in many ways, such as the determination of the important conditions, so that changes can be implemented. The implementation or exploration by means of new intervention is impossible if the situation of the organization does not change. Also, if the staffs do not have the effort to change, such as the refusal to learn the ability to adapt and to orient on growth, the process of changes will also be deflected (Lehman 2002).

The other result of this study was the quality performance variation, in which $43 \%$ of it were influenced by the individual readiness variation and organizational readiness to implement TQM, the rest were influenced by other variables. The purpose of modeling in this research is to explain and confirm the relationship between organizational readiness and individual readiness to implement TQM on quality performance, so that the effect of individual and organizational readiness on variations in quality performance by $43 \%$ were considerably high, as this represents nearly half of the causes of successful quality performance. This means that by striving for organizational readiness and individual readiness in implementing TQM the company is estimated to be almost $50 \%$ able to improve quality performance. In comparison, the research conducted by Leachman et al. (2005) concluded that the commitment of strong Research \& Development, and the ability to control the production time, had shown as much as $37 \%$ differences on manufacturing performance between producers of high volume. 


\section{CONCLUSION}

This paper contributes to the existing literature on change management by providing empirical evidence that points to advances in knowledge and understanding of the relationship between organizational readiness and individual readiness to implement TQM and the influence of both on quality performance. Furthermore, this article adds value through contextual originality; is the first study to interpret the context of organizational and individual readiness in implementing TQM in the manufacturing industry in Indonesia, and therefore contributes to completing the literature gap on both organizational readiness and individual readiness to implement TQM and its effects on quality performance, and in certain developing countries.

\section{ACKNOWLEDGMENT}

The authors would like to thank Universitas Mercu Buana (UMB) Jakarta, Indonesia, so that this research can be carried out. This research has been funded by Universitas Mercu Buana, Jakarta, through its research center.

\section{REFERENCES}

Adesta, E.Y.T. and Prabowo, H.A. 2018. Total Productive Maintenance (TPM) Implementation Based on Lean Manufacturing Tools in Indonesian Manufacturing Industries. Int. J. Engineering. Technology, 7:156-159.

Ahmad, M. F., Zakuan, N., Jusoh, A., and J. Takala. 2012. Relationship of TQM and Business Performance with Mediators of SPC, Lean Production and TPM. Procedia - Social and Behavioral Sciences, 65: 186-191.

A. Lameei. 2005. Assessment of Organization Readiness for TQM Implementation. Iran. J. Public Health, 34(2): $58-63$.

Al-maamari, Q., Kassim, R.N.M, Raju, V., Al-Tahitah, A.N., Ameen, A., Abdulrab, M., 2018. Factors Affecting Individual Readiness for Change: A Conceptual Framework. International Journal of Management and Human Science (IJMHS), 2(1): 13-18

Anvari, A., Ismail, Y., Mohammad, S., and Hojjati. H. 2011. A Study on Total Quality Management and Lean Manufacturing: Through Lean Thinking Approach. World Applied Science. Journal, 12(9): 1585-1596.

Brah, S. and Ying Lim, H. 2006. The effects of technology and TQM on the performance of logistics companie. International Journal of Physical Distribution \& Logistics Management, 36(3): 192-209.

Chase, Richard, B., Nicholas, J. Aquilano, F. Robert Jacobs. 2005. Operation Management for Competitive Advantage, Eleventh Edition, USA: McGraw-Hill Inc.

Corbett, L. M., Rastrick, K.N. 2000. Quality performance and organizational culture: A New Zealand study. International Journal of Quality \& Reliability Management, 17(1): 14-26.

Dijkstra, J., Henseler, T.K. 2015. Consistent Partial Least Squares Path Modelling. Manag. Inf. Syst. Q., 39(2): 297-316.

Dubey, R., Gunasekaran, A. 2015. Exploring soft TQM dimensions and their impact on firm performance: some exploratory empirical results. International Journal of Production Research. 53(2): 371-382.

Eby. L. 2000. Perceptions of Organizational Readiness for Change: Factors Related to Employees' Reactions to the Implementation of Team Based Selling. Human Relations," 53(3): 419-442.

Feng, J., Prajogo, D., Chuan T.K., and Sohal, A. 2006. The impact of TQM practices on performance: A comparative study between Australian and Singaporean organizations. European Journal of Innovation Management, 9(3): 269-278. 
Farida, F., Prabowo, H.A., Vidayanti, D. 2019. Evaluation of the foster program as an effort to accelerate the implementation of the quality assurance system in Indonesian private university", Academia, 16-17: 145167.

Flynn, B., Saladin, B. 2006. Relevance Of Baldrige Constructs In An International Context: A Study Of National Culture. Journal of Operations Management. 24(5): 583-603.

Forza, C., Filippini R. 1998. TQM impact on quality conformance and customer satisfaction: A causal model. International Journal of Production Economics. vol. 55, Issue 1.p 1-20.

Ghozali, A. and H. Latan. 2015. Partial Least Squares: Konsep Teknik dan Aplikasi Menggunakan aplikasi SmartPLS 3.0, Vol. 2. Semarang: Badan Penerbit Universitas Diponegoro.

Haffar, M., Al-karaghouli, W., Ghoneim. A. 2013. The mediating effect of individual readiness for change in the relationship between organisational culture and TQM implementation. Journal of Total Quality Management \& Business Excellence. 13(5-6): 693-70

Haffar, M., Al-Karaghouli, W., Ghoneim, A., (2014),"An empirical investigation of the influence of organizational culture on individual readiness for change in Syrian manufacturing organizations", Journal of Organizational Change Management, Vol. 27 Iss 1 pp. 5 - 22

Haffar, M., Al-karaghouli, W., Irani, Z., Djebarni, R., Gbadamosi. G. 2016. The influence of individual readiness for change dimensions on quality management implementation in Algerian manufacturing organisations. International Journal of Production Economics.

H. S. F. Holt, Daniels T., Achilles, Amenakis. Stanley G. Harris. 2007. Readiness for Organizational Change: The Systematic Development of a Scale. Journal of Applied Behavioral Science, 43: 232-255

Iqbal, A. Asrar-ul-Haq, M., (2018). Establishing relationship between TQM practices and employee performance: The mediating role of change readiness. International Journal of Production Economics, 203: $62-68$.

I. Sila. 2007. Examining the effects of contextual factors on TQM and performance through the lens of organizational theories: An empirical study. Journal of Operations Management. 25: 83-109.

Krajewski, L., Ritzman, L. and Malhotra, M. 2006. Operations Management, 8th ed., Pearson Prentice-Hall, Upper Saddle River, NJ, pp. 14-15.

Kull. T.J., Wacker, J.G. 2010. Quality management effectiveness in Asia: The influence of culture. Journal of Operations Management. 28(3): 223-239.

Lehman, W.E.K. 2002. Assessing Organizational Readiness for Change," Journal of Substance Abuse Treatment. 22(4): 197-209.

Leachman, S. K., Chien., Pegels, C.Carls. Shin. 2005. Manufacturing performance: evaluation and determinants. Int. J. Oper. Prod. Manag, 25(9): 851-874.

Mahmud. 2011. Metode Penelitian Pendidikan, 1st ed. Bandung: Pustaka Setia.

Mcnabb, D. E. 1995. Culture, Climate, and Total Quality Management: Measuring Readiness for Change. Public Productivity \& Management Review, 18(4): 369-385.

Meirovich, E. J., Gavriel., Romar. 2006. The difficulty in implementing TQM in higher education instruction: The duality of instructor/ student roles. Quality Assurance Education. Article. Information, 14(4): 324-337.

Munizu, S., Surahman, M., Ubud, S. 2012. Pengaruh Praktik Total Quality Management (TQM) terhadap Budaya Kualitas , Daya Saing dan Kinerja Perusahaan ( Studi pada Industri Manufaktur di Kota Makassar ). Jurnal Aplikasi Manajemen, 10: 510-519.

Novrianto, Y., Soenoko, R., and Santoso, P.B. 2014. Analisis Penerapan Total Quality Management (TQM) di Industri Pertahanan Nasional (Studi kasus pada Industri Senjata). Journal of Engineering and Management in Industrial System. 2(1): 19-25. 
Ohtaki, S., Geaorgiev, Seiichi. 2016. Evolution and implementation of quality management practices in the manufacturing sector in Eastern Europe after the end of communism: the case of Bulgaria. Int. Journal of. Quality Reliability Management, 33(6): 804-829.

Othman, I., Ghani, S.N.M., Choon, S.W., 2020. The Total Quality Management (TQM) journey of Malaysian building contractors Idris Othman, Siti Norfarahhanim Mohd Ghani, Shim Woon Choon. Ain Shams Engineering Journal, xxx: 1-8.

Pasaribu, K. 2009. Pengaruh Komitmen, Persepsi dan Penerapan Pilar Dasar TQM Terhadap Kinerja Manajerial. J. Akuntansi dan Keuangan Indonesia., 6(2): 193-220

Prabowo, H. A., Y. Bobby, and Farida. 2018. The Evaluation of Eight Pillars Total Productive Maintenance (TPM) Implementation and Their Impact on Overall Equipment Effectiveness (OEE) and Waste. Sinergi, 22(1): 13-18.

Prajogo, D. I. 2003. The relationship between TQM practices, quality performance, and innovation performance an empirical examination. International Journal of Quality \& Reliability Management, 20(8): 901-918.

Prajogo, D. I. 2005. The Comparative Analysis of TQM Practices and Quality Performance Between Manufacturing and Service Firms in Australia. International Journal of Service Industry Management, 16(3): 217-228.

Roslin, E.N., Ahmed, S., Ahamat, M. A., Bahrom, M. Z., Ibrahim. N. 2019. The Impact of Employee Involvement and Empowerment in Lean Manufacturing System Implementation towards Organizational Performances”, Inter. J. Adv. Sci. Engin. \& Info. Tech., 9(1): 188-193, 2019.

Sahooa, S., Yadaf, S., 2020. Influences of TPM and TQM Practices on Performance of Engineering Product and Component Manufacturers. Procedia Manufacturing, 43: 728-735.

Shafiq, M., Lasrado, F., \& Hafeez, K. 2019. The effect of TQM on organisational performance: empirical evidence from the textile sector of a developing country using SEM. Total Quality Management and Business Excellence, 30(1-2): 31-52.

Sila, I., and Ebrahimpour, M. 2005. Critical linkages among TQM factors and business results. International Journal of Operations \& Production Management, 25(11): 1123-1155.

Theurer, C. P., Tumasjan, A., Welpe, I. M., and Lievens. F. 2018. Employer Branding: A Brand Equity-based Literature Review and Research Agenda,” Int. J. Management. Review, 20(1): 155-179.

Vakola, M. 2013. Multilevel Readiness to Organizational Change: A Conceptual Approach, Journal of Change Management, 13(1): 96-109.

Weeks, E., Roberts, W., Chonko, J., Jones, L.B. 2004. Organizational Readiness for Change, Individual Fear of Change and Sales Manager Performance. J. Pers. Sell. Sales Manag., 24(1): 7-17.

Weiner, B., 2009. A theory of organizational readiness for change. Implementation Science, 4(67): 1-9.

Yusof, M.S., Aspinwall, E. 1999. Critical success factors for total quality management implementation in small and medium enterprises," Total Quality Management, 10(4\&5): 803-809.

Zairi, M. 2013. The TQM legacy - Gurus' contributions and theoretical impact. TQM Journal, 25(6): 659-676. 